\title{
Horticultural Crop Production Capabilities and Opportunities in the Tropics
}

\author{
Dyanand Raj Kumar ${ }^{1}$ \\ Department of Crop Science, University of the West Indies, St. Augustine, Trinidad and Tobago
}

The tropics refers to that part of the earth that lies between $23^{\circ} 27^{\prime}$ north and south latitudes. In the Western hemisphere, this includes all of Brazil north of São Paulo and Rio de Janeiro, half of Paraguay, a quarter of Chile, all of, Bolivia, Peru, Ecuador, Colombia, Venezuela, Guyana, Surinam, and French Guyana in South America, as well as all of Central America south of Mazatlán and Tampico in Mexico, and the entire Caribbean south of Havana, Cuba.

\section{Temperature and daylength}

The main characteristic of this region is the uniformly moderate temperatures that prevail throughout the year. The average temperature is around $27 \mathrm{C}$, with little variation. Indeed, the diurnal variation $(10$ to $15 \mathrm{C})$ is usually greater than the annual variation (Monteith, 1977; Samson, 1986). This stability is accompanied by relatively uniform daylengths throughout the year-at the equator, the daylength is almost a constant $12 \mathrm{hr}$, while, at the Tropics of Cancer and Capricorn, the difference between the shortest and longest day is slightly less than $3 \mathrm{hrs}$ (Webster and Wilson, 1980). Thus, temperature and daylength are conducive to-year-around plant growth. Under these conditions, the rate of plant growth is relatively fast, so that trees come into bearing earlier and the interval between planting and harvesting (e.g., in vegetables) is less than in subtropical or temperate regions. Similarly, the interval between bloom and maturity in fruits is shorter (Cassin et al., 1969).

\section{Rainfall and soils}

In the tropics, water and oxygen stresses are frequently the major limiting factors to plant growth. Rainfall is usually unevenly distributed, resulting in alternating wet and dry seasons. These seasons are quite distinct between 5" and 15" north and south of the equator. Within 5" north and south, there is some rain in every month of the year, although two or three months maybe less wet than the others (Webster and Wilson, 1980). During the wet season, rainfall exceeds evapotranspiration, as well as the soil's capacity to absorb and store water, resulting in leaching and erosion as well as anaerobic soil conditions (Gumbs and Lindsey, 1982). In such situations, soils tend to have low cation exchange capacities, low amounts of exchangeable bases, high aluminum saturation, high phosphorus fixation, and easily disturbed nutrient balances (Bennema, 1977). During the dry season, there is often inadequate soil moisture for crop production because the excess water from the rainy season is allowed to run into the sea and/or there is not the infrastructure for providing irrigation.

\section{Crop protection}

The equable climatic conditions in the tropics induce not only the growth of plants, but also weeds and pests. Weed growth is prolific once there is adequate soil moisture (Webster and Wilson, 1980). Weeds compete with the crop for nutrients and soil moisture, create undesirable microclimates by increasing humidity in the crop environment, and act as alternate hosts for pests and diseases (Samson; 1986). Maintaining weed-free conditions is expensive and exposes the soil to severe erosion (Gumbs and Lindsey, 1982). Controlling weeds using current technology also means using scarce foreign monetary exchange to purchase herbicides manufactured in the non-tropical world. Similarly, diseases and other pests are usually controlled using imported pesticides that are applied using techniques and rates developed under non-tropical conditions.

lecturer.

\section{The need for research}

There is a need for research directed at understanding tropical ecosystems and how to manage them with a view to producing the required quantity and quality of product with minimal pollution of the environment, exodus of foreign exchange, soil loss by erosion, etc.

Some progress has been made along these lines. For example, it has been determined that the protozoan flagellate Phytomonas elmassiani Migone, which causes Cedros wilt in-coconuts, is transmitted from milkweed (Asclepias curassavica L.) by the milkweed bug (Oncopeltus cingulifer Stal.). Ridding coconut fields of milkweed stops the spread of the disease (Griffith, 1981).

The understanding of some aspects of the plant-environment interaction has permitted the production of some temperate crops in the tropics. For example, apple trees produce five crops in 2 years in Indonesia (Janick, 1974; Notodimedjo et al., 1981; Saure, 1973), as do grape vines growing at sea level in Venezuela (Corzo, 1987). If properly managed under tropical conditions, these plants do not go dormant and are induced to flower two or more times per year (Edwards, 1987). However, the quality of the fruit differs from that produced in cooler climates: fruits maybe smaller (Michelini, 1987) or may not develop normal color or soluble solids content (van Balen, 1987). It may be possible to manipulate fruit quality, e.g., by the use of growth regulators, if required by the market.

Even in as important a crop as citrus, relationships between climatic, edaphic, and biotic factors and yield in the tropics have not been fully elucidated (Reuther, 1973). It is known that flower induction in oranges is due to water stress and that blooming occurs 20 to 28 days after relief of the stress (Samson, 1986). However, to quote Reuther (1973), "locally developed research information on fertility, irrigation, plant protection and related cultural problems is for the most part lacking in tropical areas. "There clearly is a great need for well-directed research into the various aspects of crop production over a wide range of species in the tropics.

To achieve this research capability, it is essential to develop cadres of well-trained, highly motivated scientists in tropical countries and provide them with the necessary facilities to carry out such work. In addition, it is essential that effective extension systems be implemented to transmit the results to farmers quickly for such work to have a meaningful impact on the production of crops.

When one considers that there are $<20$ major fruit crops in international trade (Samson, 1986), whereas there are $>3000$ species of tropical fruits (Martin et al., 1987), it begins to become apparent that there is a huge repository of species in the tropical world waiting to be developed for the benefit and enrichment of mankind. This is equally true of vegetables, spices, and medicinal and ornamental plants. The question is which one to develop first and how to go about it.

\section{Diversification}

In recent times, tropical countries have been seeking to diversify their agricultural production to reduce their dependence on the traditional plantation crops such as coffee, cacao, or bananas. Horticultural crops have often been seen as desirable enterprises in these diversification programs because of their high market value. Unfortunately, this is frequently more illusory than real. Although many tropical horticultural products retail at high prices, by far the majority of that retail price is absorbed along the marketing chain, with the tropical farmer receiving as little as $3 \%$ to $10 \%$ of the final price (Raj Kumar, 1988). Increasing numbers of tropical farmers 
will learn this lesson to their chagrin, as they diversify into highly touted crops (Thompson, 1988). This may have serious social implications, such as upheavals by disenchanted farmers and their families against marketers, middlemen, and even governments.

Therefore, it is essential that proper feasibility and market studies be done before any country or organization decides to seriously go into the production of any new horticultural product for export. According to Winter (1985), such a feasibility study should assess the market potential in relation to the country's production period; review market requirements by cultivars vis-à-vis the country's crops; estimate likely F.O.B. returns; identify likely trading partners; review the production base for produce suitability, location and scale; review the infrastructural and institutional aspects in the country, identifying gaps and shortcomings and recommending how these should be rectified; and carry out a full financial and economic appraisal of the proposed export industry. The market study for each product will need to determine the size of the market for the product; present and imminent competitors and their relative advantages and disadvantages; trade preferences for types, cultivars, and quality; prices at different times of the year and for products from different sources; distribution channels and marketing structures; price distribution throughout that structure; handling, packing, shipping, and storage requirement tariff and non-tariff barriers (e.g., phytosanitary regulations); preferred terms of trade (e.g., consignment or outright purchase); trends in the market; and major ports of entry and facilities that exist at these points.

Once these studies indicate acceptable economic and social results, the advantages of the given tropical environment can then be exploited. These include the naturally conducive conditions for plant growth, often the availability of a wide diversity of germplasm due to heterogeneity and absence of selection in many tropical species and the existence of abundant, inexpensive labor in many tropical countries.

However, there are many constraints to the production of horticultural crops in the tropics, especially crops destined for export as fresh products. The amount and quality of information available is generally very limited. Moreover, the necessary human and other resources to do research and development and to extend these findings to farmers are also inadequate or ineffective. Throughout the tropics, infrastructure to support the growing and marketing of fresh horticultural produce for export is either non-existent or inadequate, resulting in larger proportions of culls and, consequently, reduced returns to the farmer.

Many tropical farmers occupy small parcels of land and lead tenuous financial lives. They do not have the resources to either invest in high-capital projects, such as commercial floriculture, or survive while they wait on pure stands of tree crops to come into production. As a result, they try to combine different enterprises, which results in a mix that may not be ideal for any one of the components. This may be acceptable or even desirable for some production systems, but it is not compatible with the exacting demands of the export market for fresh horticultural products. Indeed, the small farmer is often unaware of these demands and has no knowledge of the market for or marketing of these crops. However, that does not preclude him or her from this area of activity. For example, numerous small farmers grow bananas for export as fresh fruit in the Windward Islands of the West Indies. Coordination of all aspects of such a production program, from research through extension, production, and marketing, is essential if it is to be successful.

There are also other criteria to be satisfied. In the two largest markets, North America and Western Europe, imported horticultural products are trucked long distances from their points of entry. Such products must be packaged in standard size and quality containers to fit the trucks' conformation and withstand the journey (Johnson, 1986). Plant quarantine regulations may debar certain products or require expensive treatment, such as irradiation. In many of the undeveloped species, optimal stage of maturity, packing, handling, and storage and shipping conditions for export are not known. These criteria differ for almost every horticultural product. Therefore, new entrants to the trade are better advised to keep their product range small and use their limited resources to master the constraints associated with such a range, rather than try to handle a wide product mix and not be able to service any one part of that mix adequately.

\section{A political dimension}

Tropical climates are amenable to crop growth, but there is a political dimension to the problem. The importance of providing basic infrastructure such as roads, irrigation water, electricity, and telephones to farming communities needs to be recognized and given priority by political directorates.

Any effort at producing a new horticultural crop for export will demand financial support that is greater than that available to most private farmers. Research and development and marketing and promotion require large budgets that generate no immediate paybacks. Governments have a pivotal role to play in these and other areas (Winter, 1985). Governments, either directly or through some agency, need to commission feasibility and market studies; support research, development, and extension; provide credit facilities, training, and market intelligence on an on-going basis; and provide market development and promotion. There are many examples to prove this point. One is the success of israeli avocadoes in France (La Rosa, 1985). The importation of avocadoes into France rose from $800 \mathrm{t}$ in 1966 to 51,000 tin 1983, of which Israel supplied 500 and 35,000 $\mathrm{t}$, respectively. The Israeli state-owned company, AGREXCO, encouraged the planting of the acceptable cultivars Fuerte, Hass, and Ettinger. Recognizing that success in exports depends on the quality of the product, homogeneity, and regulation of export consignments, AGREXCO, together with the Fruit Board, instituted a quality control program on production, grading, and packing and organized the shipping and distribution of the fruit to wholesalers/distributors in France. This was backed up by promotional campaigns, which, in the early years, "had budgets that were colossal in comparison with turnover" (La Rosa, 1985).

\section{Conclusion}

The international market for new tropical horticultural products is opening up, providing opportunities for exports of fruit, vegetable, and ornamental plant products. Many of these grow easily and well in the tropics, where there is often a wide, natural germplasm base. To exploit these advantages, products for export must be carefully chosen, based on thorough feasibility and market studies. Thereafter, production and marketing systems that are compatible with the environment, ecology, economy, and sociology of the country will have to be developed. These systems must provide products in a form, at a time, and at a price that is acceptable to the importing market and that will be able to compete with similar or alternative products from elsewhere. All sectors of the producing economy, state, private enterprise and labor, small and large farmer, marketer, researcher, and financier have a role to play if any new product is to become established in the international market.

\section{Literature Cited}

Bennema, J. 1977. Soils, p. 29-55. In: P. de T. Alvim and T.T. Kozlowski (eds.). Ecophysiology of tropical crops. Academic, New York.

Cassin, J., J. Bourdeaut, A. Fougue, V. Furon, J.P. Gaillard, J. LeBourdelles, G. Montagut, and C. Moreuil. 1969. The influence of climate upon the blooming of citrus in tropical areas. Proc. First Intl. Citrus Symp. 1:315-323,

Corzo, P. 1987. Tropical viticulture in Venezuela. Acta Hort. 199:27-29.

Edwards, G.R. 1987. Potential for apple production in Venezuela. Acts Hort. 199:19-25.

Edwards, G.R. 1987. Producing temperate-zone fruit at low latitudes: Avoiding rest and the chilling requirement. HortScience 22:1236-1240.

Griffith, R. 1981. The origin and mode of transmission of Cedros wilt disease of coconuts. J. Agr. Soc. Trinidad and Tobago. 81(1):74-104.

Gumbs, F.A. and J.I. Lindsay. 1982. Water runoff and soil erosion from an ultisol under different crops and soil management. Soil Sci. Soc. Amer. Proc. 46:1264-1266.

Janick, J. 1974. The apple in Java. Hortscience 9:13-15.

Johnson, J. (ed.) 1986. 1986 Floral marketing directory and buyer's guide. Floral Marketing Division of the Produce Marketing Assn., Newark, Del.

LaRosa, A. 1985. Tropical fruit-getting to grips with a worthwhile mar- 
ket. The Courier no. 92. July-August. p. 89-91.

Martin, F. W., C.W. Campbell, and R.M. Ruberté. 1987. Perennial edible fruits of the tropics. An inventory. USDA Agr. Hdbk. 642.

Michelini, S. 1987. Temperate fruits in Barbados. Acta Hort. 199:32.

Monteith, J.L. 1977. Climate, p. 1-27. In: P. de T. Alvim and T.T. Kozlowski (eds.). Ecophysiology of tropical crops. Academic, New York.

Notodimedjo, S., H. Danoesastro, S. Sastrosumarto, and G.R Edwards. 1981. Shoot growth, flower initiation and dormancy of apple $m$ the tropics. Acts Hort. 120:179-186.

Raj Kumar, D. 1988. Cut flowers - A growing business for big and small. Hort. Soc. Trinidad and Tobago Annu. 1988:9-19.

Reuther, W. 1973. Climate and citrus behavior, p. 280-337. In: W. Reuther (cd.). The citrus industry. vol. 111. Univ. of Calif., Berkeley.
Samson, J.A. 1986. Tropical fruits, 2nd ed. Longman, London.

Saure, M. 1973. Successful apple growing in Indonesia. Fruit Var. J. 27:4445.

Thompson, V. 1988. Winter vegetable production - The Grace Kennedy and Company Ltd. experience. Proc. Farm-tech '85: Modern technology for Jamaican agriculture. Faculty of Agr., Univ. of the West Indies, Trinidad.

van Balen, J. 1987. Potential for wine production in Venezuela. Acta Hort. 199:30.

Webster, C.C. and P.N. Wilson. 1980. Agriculture in the tropics, 2nd ed. Longman, London.

Winter, J.D. 1985. Guidelines for establishment of tropical fruit export industries. The Courier no. 92. July-August. p. 92-97.

\title{
Techniques for Producing Export-quality Tropical Horticultural Crops
}

\author{
Carl W. Campbell \\ University of Florida, Tropical Research and Education Center, \\ 18905 SW 280th Street, Homestead, FL 33031
}

Tropical horticultural crops have been established in international trade for a long time. Banana and pineapple are good examples. Many crops, however, have been little-known outside the tropics until recently, when a growing interest in new and different fresh commodities in developed countries has stimulated increased export trade from the tropics. Many governments look upon this trade as a good way to earn foreign exchange and to increase employment in their countries.

Some tropical horticultural crops, particularly herbaceous species, have a tradition of production by relatively formalized procedures. With others, particularly tree crops, cultivation is less formal. These often are planted in gardens, pastures, parks, or roadside areas; some are harvested from the forest. Care of crops grown in this way is usually casual and the fruit is sold in local markets or consumed locally. It is difficult with crops such as these to convince growers that more formalized culture is necessary or economically justified. Improvement in care must be made, however, if horticultural crops of sufficiently high quality for export are to be produced.

\section{PRODUCTION INFORMATION}

Efficient production requires basic information on all aspects of growing the crop. For a few tropical horticultural crops, extensive information has been acquired through research. Examples include fruit crops such as avocado, banana, citrus, mango, papaya, and pineapple; vegetables such as cucumber, green beans, pepper, and tomato; floral crops such as anthurium, carnation, chrysanthemum, and rose; and various foliage plants.

For many crops, however, relatively little information on production is available; e.g., acerola, atemoya, breadfruit, carambola, guava, mamey sapote, passion fruit, soursop, winged bean, and chayote, among others. The information available is scattered through a variety of bulletins, books, and unpublished reports in many countries and is difficult to retrieve.

Fortunately, there is a strong trend now for governments and development agencies to support the compilation of research information bases as an early step in crop-oriented development projects. Information collected through literature searches is critically reviewed and organized into forms that can be used as guides to production. As searches are made, areas of information deficiency become apparent that serve as directions for future research.

Until recently, most agricultural information has been organized into conventional reports, bulletins, or circulars. This method still has value, but recently there has been an increasing trend to computerize agricultural databases. In Florida, for example, databases have been developed for such horticultural crops as avocado, lime, mango, snapbeans, strawberry, and tomato. Computerized databases have the great advantage that they can be updated easily with respect to information that changes frequently, such as pesticide recommendations. With the growing availability and use of computers throughout the world, these databases can be powerful tools in the dissemination of agricultural technology.

Simply accumulating information is not enough; it must be communicated effectively to producers through activities known as extension or technology transfer. Some countries or organizations have effective extension services, but most do not. The development and implementation of an effective extension mechanism is one of the basic components of a good development program. This need is generally understood and agreed upon by everyone involved, but often difficult to accomplish, usually for political reasons. Those who do the research are in a different governmental agency than the people who are supposed to disseminate the information. Resolution of this problem is a worthy goal.

\section{CROP SELECTION}

A critical step in horticultural crop development is the choice of crops to be emphasized. Success depends on selecting those that are reasonably well-adapted to the area and marketable. Adaptation testing is essential for any crop that is new to an area. To some extent, adaptation can be predicted from crop performance in similar regions, but there are too many variables involved to be certain of success without testing in specific locations. When it is determined which crops to grow, producers need to obtain good planting stock. This often requires initial introductions of seed or vegetative propagules from public or private sources in other countries. Introduction of plant materials from other countries should be controlled by a quarantine system adequate enough to prevent inadvertent introduction of pests or diseases.

Some crops can be propagated satisfactorily from seed. Many can only be propagated true-to-type by vegetative propagation. With many tropical crops, both seed and vegetative propagules are shortlived after removal from the plants on which they were produced. Improvements in packaging and transportation methods have helped greatly in long-distance transport of tropical plant material. Recent developments in tissue culture methods offer the possibility of tremendous improvement in propagation and dissemination of diseasefree propagules of tropical crops. Some species are already being propagated in this way. However, tissue culture methods remain to be developed for most woody species.

A desirable long-term goal of a plant introduction program is the 